\title{
PREVALENCE OF PSYCHOSOCIAL RISK FACTORS IN SELECTED INDUSTRIES IN LATVIA
}

\author{
Lāsma Kozlova $^{\#}$ and Svetlana Lakiša \\ Institute of Occupational Safety and Environmental Health, Rīga Stradiṇš University, Dzirciema iela 16, Rīga, LV-1007, LATVIA \\ lasma.kozlova@rsu.lv \\ \# Corresponding author
}

Communicated by Modra Murovska

\begin{abstract}
The hypothesis of the study was that psychosocial risk factors are more common in industries involving intellectual work, such as education and public administration (Group 1), rather than in industries like construction, agriculture, and forestry where physical work is more common (Group 2). This hypothesis was confirmed and the important findings were that the most common psychosocial risk factors in Group 1 were staff conflicts, conflicts with managers and clients, also lack of time and having to communicate with clients during the working day. Violence, especially physical and psychological violence was a common risk factor in Group 1; mostly the client caused the violence. In Group 2 the most common psychosocial risk factors were overtime work, conflicts with managers, lack of time and having to communicate with clients during the working day. Overtime work was the most common risk factor in construction, agriculture, and forestry industries.
\end{abstract}

Key words: prevalence, psychosocial risk factors, education, construction, forestry, agriculture, administration.

\section{INTRODUCTION}

The International Labour Organisation defines psychosocial risks as the interaction between and among work environment, job content, organisational conditions, and workers' capacities, needs, culture, personal extra-job considerations that may, through perceptions and experience, influence workers' health, work performance and satisfaction (Anonymous, 1986). The common psychosocial risk factors can be divided into two groups - ones that refer to the job itself (work schedule, job content, workload and workpace, work environment, and equipment) and to the working environment (the control one has over workload, organisational culture and function, interpersonal relationships at work, ones role in the organisation, career development, and home-work interface) (Anonymous, 2010). This discrepancy between one's responsibilities and individual capability to meet them can cause stress, which can affect human health and well-being. Stress is linked to causing "burnout syndrome" - described as an inadequate reaction to chronical emotional stress, with symptoms like fatigue, depersonalisation, changes in one's attitude towards work and interactions among colleagues (Eglīte, 2012). Shift work can cause sleep deprivation, chronic fatigue and increase the number of occupational accidents due to lack of concentration and attention from an employee (Goetsch, 2015) and shift work that involves circadian disruptions is classified as "probably carcinogenic to humans" (Anonymous, 2010). The common effects on physical health are musculoskeletal disorders, coronary heart disease, bowel disfunction, ulcers and other digestive system problems, headaches, and decreased immunity, which result in more sick leave days (Eglìte, 2012). Work-related psychosocial risks and stress are now considered as the "new and emerging" area of Occupational Safety and Health (Anonymous, 2016a; 2016b) and have been acknowledged by the European Commission in the Strategic Framework on Health and Safety at Work 2014-2020 where "improving the prevention of workrelated diseases by tackling existing, new and emerging risks" is one of the three major challenges (Anonymous, 2014). In a study about exposure to occupational health risk factors and stress at work in Europe, the most common causes of stress at work were identified as the lack of stability $(72 \%)$ and overtime work $(66 \%)$. All kinds of violence (verbal, emotional, physical) rank as the third most common cause of stress at work, and women are more likely to be affected by stress at work than men (Anonymous, 2013a).

Teachers in Latvia experience violence in their workplace $-56 \%$ of respondents had experienced emotional violence in their workplace and $85 \%$ responded that they were mocked by their students (Anonymous, 2008). In a different study the most common cause of stress was lack of communication between colleagues and poor relationships with managers (Eres and Atanasoska, 2011).

Workers in construction, forestry and agriculture are also exposed to psychosocial risk factors. In a study carried out 
in the United Kingdom, $68.2 \%$ respondents working in the construction industry $(\mathrm{n}=857)$ had suffered from stress, anxiety, and depression. More than one half (58.2\%) thought that the stress level in construction industry had risen in the past five years and $84.8 \%$ admitted that not enough attention is drawn to possible psychological problems associated with working in the construction industry (Campbell, 2006).

This study examines the prevalence of psychosocial risk factors in two different occupational groups - public administration and education group (white collar workers) and forestry, agriculture, and construction group (blue collar workers). These groups were chosen to estimate the difference of prevalence of psychosocial risk factors between a group where the job is rather psychological than physical (white collar workers) and the other where work is more physical than mental (blue collar workers).

The hypothesis of this study was that psychosocial risk factors are more common in industries of intellectual work such as education and public administration (Group 1) rather than in industries where physical work is more common (construction, agriculture and forestry) (Group 2)).

\section{MATERIALS AND METHODS}

Data used in this study was taken from a large national study, "Working conditions and risks in Latvia, 20122013". The data was collected using interviews with workers conducted during the period from January to February 2010. The study sample was random, using a combined approach of quotas (no less than 50 interviews per sector) and stratified random sampling method. The respondents were approached at their homes, and were interviewed using a Computer Assisted Personal Interview (CAPI). A total of 2505 employees from the general population of workers in Latvia ( $n=1070$ 900) were included in the study sample. The sampling had four stages — firstly, each sector was given a quota for interviews (no less than 50, based on the count of enterprises in this industry). Secondly, 260 areas were chosen in the territory of Latvia, each given 10 interviews. In these areas the interviewer was given an address - street name, house number where no interviews had been made in the past year. Thirdly, the interviewer went to every $5^{\text {th }}$ apartment, every $2^{\text {nd }}$ house or every nearest farmhouse. The last stage was to interview a person at the specific home, who met the criteria of the target group - aged 18-74 years, employed and receiving salaries, is on parental leave (up to 1.5 years), or self-employed and currently at home.

The results were analysed in two ways - by examining the data on prevalence of psychosocial risk factors at work in selected industries in Latvia and also in industry groups. Industries in this study were divided according to the International NACE Classification. The analysed industries were divided into two groups. Education and public administration were combined into one group (Group 1), and construc- tion, forestry, and agriculture in the second (Group 2). Group 1 consisted of 403 respondents, mostly female $(74.9 \%, \mathrm{n}=302)$, with mean age 44.2 years $(\mathrm{SD}=11.8)$. Group 2 consisted of 404 respondents, mostly men $(75.0 \%$, $\mathrm{n}=303)$, with mean age 41.7 years $(\mathrm{SD}=11.7)$. The main reason for grouping these industries was that education and public administration are traditionally seen as occupations where work is more mental than physical, and work in construction, forestry and agriculture as requiring more physical strength.

Respondents were asked to answer several questions to describe their work environment and psychosocial risk factors at work, such as their exposure to overtime work, conflicts, violence, lack of time and control over the pace and quantity of their work. Respondents had to evaluate what part of the working day they were exposed to risk factors on the scale from 1 to 8 ( 1 - always, 7 - never, 8 - hard to say). The question for job satisfaction had 5 answers (1 - very satisfied, 4 - unsatisfied, 8 - hard to say).

IBM Statistics SPSS v.20 was used to analyse the data. Methods as Crosstabs, Chi-square test $\left(\chi^{2}\right)$ and Confidence Interval of $95 \%$ were used to analyse the prevalence of psychosocial risk factors in selected industries in Latvia.

\section{RESULTS}

The results obtained in this study are shown firstly in selected industries (education, public administration, forestry, construction, and agriculture) and then psychosocial risk factors in the workplace are compared between the two industry groups.

\section{Prevalence of psychosocial risk factors in education and public administration}

Job satisfaction is one of the indicators showing how well a person feels in his work environment. Results show that $87.3 \%(\mathrm{n}=352,95 \% \mathrm{CI} \pm 3.3 \%)$ Group 1 respondents were satisfied with their job and that the most common reasons of satisfaction (Fig. 1) were that the job was interesting and creative $(52.8 \%, \mathrm{n}=186,95 \% \mathrm{CI} \pm 4.9 \%)$, the certainty of the job $(48.6 \%, \mathrm{n}=171,95 \% \mathrm{CI} \pm 4.9 \%)$ and also social insurance $(47.7 \%, \mathrm{n}=168,95 \% \pm 4.9 \%)$. Answers to a ques-

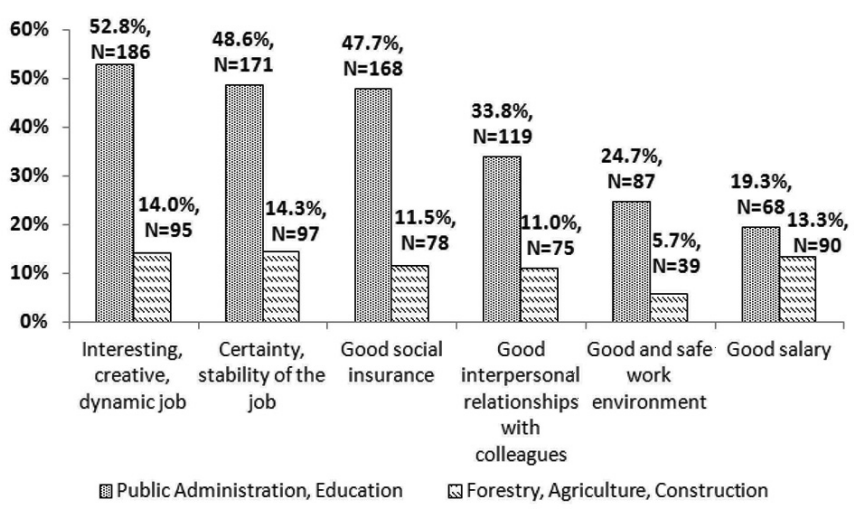

Fig. 1. Reasons for job satisfaction in educational and public administration industries. 
tion why respondents were not satisfied with their jobs showed that the biggest reason of dissatisfaction was a small salary $(78.0 \%, \mathrm{n}=39,95 \% \mathrm{CI} \pm 4.0 \%)$, lack of stability and irregular payments $(34.0 \%, \mathrm{n}=17,95 \% \mathrm{CI} \pm 4.6 \%)$.

The most common psychosocial risk factors in the workplace in this industry group were conflicts, interpersonal competition between colleagues, and psychological violence (Fig. 2). Most of the conflicts in the workplace in educational and public administration workers were between employees and their employers $(61.6 \%, \mathrm{n}=249,95 \% \mathrm{CI} \pm$ $4.8 \%)$, followed by conflicts with colleagues $(58.8 \%, \mathrm{n}=$ $237,95 \% \mathrm{CI} \pm 4.8 \%)$ and clients $(53.8 \%, \mathrm{n}=217,95 \% \mathrm{CI}$ $\pm 4.9 \%$ ). $49.6 \%$ respondents in this group experienced interpersonal competition in their work places $(n=200,95 \%$ CI $\pm 4.9 \%$ ).

Psychological violence in this industry group was more common than physical or sexual violence (Fig. 2). Onethird of respondents $(31.3 \%, \mathrm{n}=126,95 \% \mathrm{CI} \pm 4.5 \%)$ were exposed to psychological violence, $13.2 \%(\mathrm{n}=53,95 \% \mathrm{CI}$ $\pm 3.3 \%)$ to physical violence, and $1.2 \%(\mathrm{n}=5,95 \% \mathrm{CI} \pm$ $1.1 \%$ ) replied that they experienced sexual violence in their workplace. Those who answered that they experienced psychological violence in their workplace replied that clients and pupils and their parents $(20.6 \%, \mathrm{n}=83,95 \% \mathrm{CI} \pm$ $3.9 \%$ ) usually were the ones who were violent, followed by managers, employers $(5.7 \%, \mathrm{n}=25,95 \% \mathrm{CI} \pm 2.5)$ and colleagues $(5.0 \%, \mathrm{n}=20,95 \% \mathrm{CI} \pm 2.1 \%)$.

Lack of time, overtime work, night and shift work were common psychosocial risk factors in education and public administration workers (Fig. 3). More than one half of respondents $(62.5 \%)$ replied that they experienced lack of time in their workplace $(n=251,95 \% \mathrm{CI} \pm 4.7 \%)$ and $36.7 \%$ worked overtime $(n=148,95 \% \mathrm{CI} \pm 4.7 \%)$. Shift work and night work were risk factors for almost $20 \%$ respondents in this industry group.

Limited ability to control one's own workload, pacing, etc., were psychosocial risk factors that were not common in educational and public administration work places in Latvia - $91.0 \%$ respondents $(\mathrm{n}=367,95 \% \mathrm{CI} \pm 2.8 \%)$ answered that they can control the planning of their work and $94.0 \%$

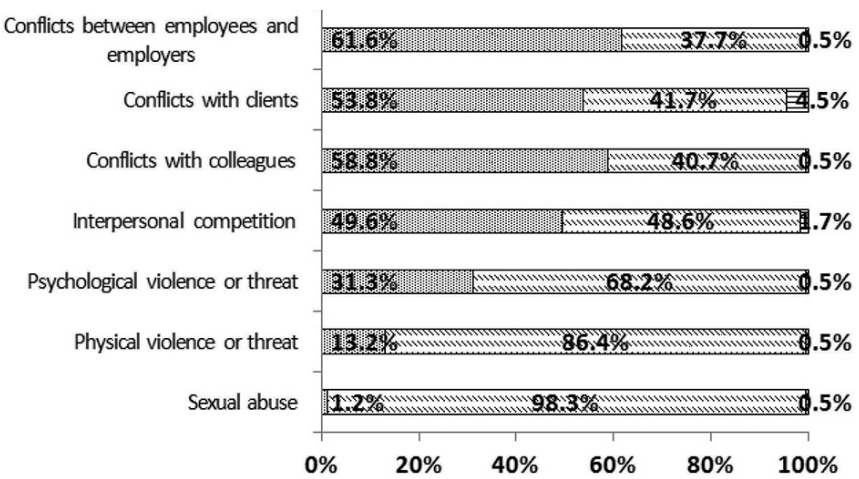

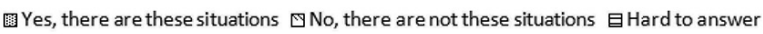

Fig. 2. Most common psychosocial risk situations in education and public administration.

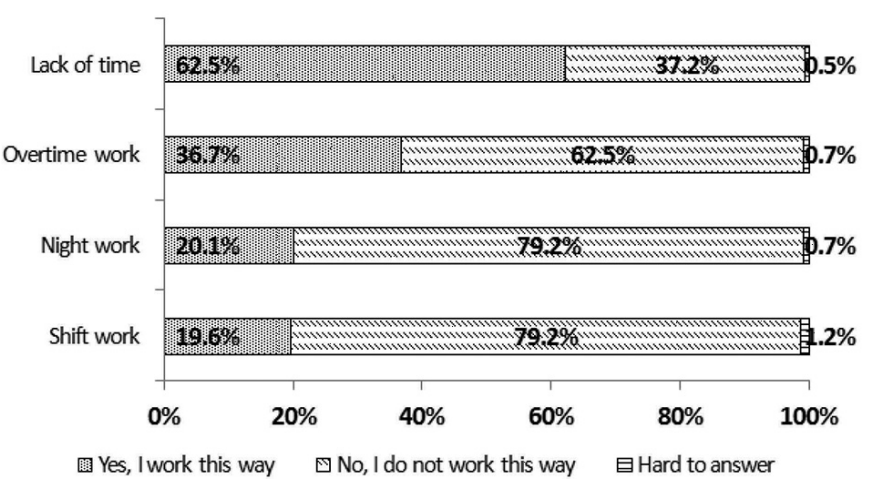

Fig. 3. Lack of time, overtime, night and shift work in education and public administration.

$(\mathrm{n}=379,95 \% \mathrm{CI} \pm 2.3 \%)$ that they can influence their job pace (Table 1).

Table 1

COMPARISON OF PREVALENCE OF VIOLENCE AND LACK OF TIME BETWEEN INDUSTRIES AND THEIR GROUPS

\begin{tabular}{|c|c|c|c|c|c|c|c|}
\hline \multicolumn{8}{|c|}{ Physical violence } \\
\hline & $\begin{array}{c}\text { Public ad- } \\
\text { ministration }\end{array}$ & Education & $\begin{array}{c}\text { Forestry, } \\
\text { agriculture }\end{array}$ & $\begin{array}{c}\text { Construc- } \\
\text { tion }\end{array}$ & $\chi^{2}$ & df & $p$ \\
\hline+ & $17.6 \%$ & $9.7 \%$ & $3.6 \%$ & $1.1 \%$ & 38.6 & 3 & $<0.001$ \\
\hline- & $82.4 \%$ & $90.3 \%$ & $96.4 \%$ & $98.9 \%$ & & & \\
\hline+ & \multicolumn{2}{|c|}{$13.2 \%$} & \multicolumn{2}{|c|}{$2.3 \%$} & 29.6 & 1 & $<0.001$ \\
\hline- & \multicolumn{2}{|c|}{$86.8 \%$} & \multicolumn{2}{|c|}{$97.7 \%$} & & & \\
\hline
\end{tabular}

Psychological violence, threat

\begin{tabular}{cc|cc|c|c|c|c}
\hline & $\begin{array}{c}\text { Public ad- } \\
\text { ministration }\end{array}$ & Education & $\begin{array}{c}\text { Forestry, } \\
\text { agriculture }\end{array}$ & $\begin{array}{c}\text { Construc- } \\
\text { tion }\end{array}$ & $\chi^{2}$ & df & $p$ \\
\hline+ & $34.5 \%$ & $28.9 \%$ & $13.9 \%$ & $16.0 \%$ & 29.4 & 3 & $<0.001$ \\
- & $65.5 \%$ & $71.1 \%$ & $86.1 \%$ & $84.0 \%$ & & & \\
+ & $31.3 \%$ & $15.0 \%$ & 27.5 & 1 & $<0.001$ \\
- & $68.7 \%$ & $85.0 \%$ & & &
\end{tabular}

\begin{tabular}{l|c|c|c|c|c|c|c}
\multicolumn{2}{l}{ Lack of time } \\
\hline $\begin{array}{c}\text { Public ad- } \\
\text { ministration }\end{array}$ & Education & $\begin{array}{c}\text { Forestry, } \\
\text { agriculture }\end{array}$ & $\begin{array}{c}\text { Construc- } \\
\text { tion }\end{array}$ & $\chi^{2}$ & $\mathrm{df}$ & $p$ \\
\hline+ & $65.5 \%$ & $60.4 \%$ & $58.3 \%$ & $65.0 \%$ & 2.8 & 3 & 0.4 \\
- & $34.5 \%$ & $39.6 \%$ & $41.7 \%$ & $35.0 \%$ & & & \\
+ & $62.7 \%$ & $61.8 \%$ & 0.1 & 1 & 0.8 \\
- & $37.3 \%$ & $38.2 \%$ & & &
\end{tabular}

Ability to plan own work

\begin{tabular}{ccccccc|c|c}
\multicolumn{2}{c}{ Ability to plan own work } \\
\hline $\begin{array}{c}\text { Public ad- } \\
\text { ministration }\end{array}$ & Education & $\begin{array}{c}\text { Forestry, } \\
\text { agriculture }\end{array}$ & $\begin{array}{c}\text { Construc- } \\
\text { tion }\end{array}$ & $\chi^{2}$ & $\mathrm{df}$ & $p$ \\
\hline+ & $87.6 \%$ & $94.2 \%$ & $92.4 \%$ & $91.2 \%$ & 5.8 & 3 & 0.1 \\
- & $12.4 \%$ & $5.8 \%$ & $7.6 \%$ & $8.8 \%$ & & & \\
+ & $91.0 \%$ & $91.7 \%$ & 0.5 & 1 & 0.8 \\
- & $9.0 \%$ & $8.3 \%$ & & &
\end{tabular}

\begin{tabular}{cc|c|c|c|c|c|c}
\multicolumn{2}{l}{ Ability to control job tempo } \\
\hline $\begin{array}{c}\text { Public ad- } \\
\text { ministration }\end{array}$ & Education & $\begin{array}{c}\text { Forestry, } \\
\text { agriculture }\end{array}$ & $\begin{array}{c}\text { Construc- } \\
\text { tion }\end{array}$ & $\chi^{2}$ & df & $p$ \\
\hline+ & $92.0 \%$ & $96.0 \%$ & $95.9 \%$ & $93.9 \%$ & 3.8 & 3 & 0.3 \\
- & $8.0 \%$ & $4.0 \%$ & $4.1 \%$ & $6.1 \%$ & & & \\
+ & $94.0 \%$ & $94.9 \%$ & 0.1 & 1 & 0.7 \\
- & $6.0 \%$ & $5.1 \%$ & & &
\end{tabular}

+, satisfied; -, dissatisfied 
Prevalence of psychosocial risk factors in construction, forestry and agriculture. Most of the respondents who answered the question $(86.9 \%, \mathrm{n}=351,95 \% \mathrm{CI} \pm 3.3 \%$ ) about their job satisfaction were pleased with their job $(62.4 \%, \mathrm{n}=252,95 \% \mathrm{CI} \pm 4.7 \%)$ but $24.5 \%(\mathrm{n}=99,95 \%$ $\mathrm{CI} \pm 4.2 \%$ ) responded that they were dissatisfied with their job. The most common reasons for job satisfaction (Fig. 1) were stability and certainty of the job and regular salaries $(14.3 \%, \mathrm{n}=97,95 \% \mathrm{CI} \pm 3.4 \%)$, the dynamics of the job $(14.0 \%, \mathrm{n}=95,95 \% \mathrm{CI} \pm 3.4 \%)$, and good salaries $(13.3 \%$, $\mathrm{n}=90,95 \% \mathrm{CI} \pm 3.3 \%)$. For those who responded that they were dissatisfied with their job (24.5\%), the most common reasons for dissatisfaction were low salary $(17.8 \%, \mathrm{n}=72$, $95 \% \mathrm{CI} \pm 3.7 \%)$ and insecurity of the job $(10.4 \%, \mathrm{n}=42$, $95 \% \mathrm{CI} \pm 2.9 \%)$.

Conflicts in the workplace were a psychosocial risk factor to those working in construction, forestry, and agriculture (Fig. 4). From all who answered to this question $(86.9 \%$, $\mathrm{n}=351,95 \% \mathrm{CI} \pm 3.3 \%)$, more than one half $(54.2 \%, \mathrm{n}=$ $219,95 \% \mathrm{CI} \pm 4.9 \%$ ) responded that there were conflicts between employees and employers in their workplace, $44.3 \%(\mathrm{n}=179,95 \% \mathrm{CI} \pm 4.9 \%)$ reported having conflicts between colleagues in their workplace and $34.7 \%(n=140$, $95 \% \mathrm{CI} \pm 4.7 \%$ ) respondents answered that interpersonal competition was present in their work environment. One-fourth of respondents $(25.5 \%, \mathrm{n}=36,95 \% \mathrm{CI} \pm 2.8 \%)$ responded that they had to deal with conflicts with clients.

Psychological violence was more common than physical violence or sexual abuse (Fig. 4). 12.9\% ( $n=36,95 \%$ CI \pm $2.8 \%$ ) responded that there were situations of psychological violence in their workplaces, $2.0 \%(\mathrm{n}=8,95 \% \mathrm{CI} \pm 1.4 \%)$ reported physical violence and none of the respondents answered that they were exposed to sexual abuse in their workplace. The most common source of psychological violence in Group 2 was the manager of the organisation. From those who answered this question $(\mathrm{n}=52,95 \% \mathrm{CI} \pm 3.27$ $\%$ ), in most cases the violent person was the employer $(71.2 \%, \mathrm{n}=35,95 \% \mathrm{CI} \pm 12.3)$.

Among $86.9 \%(\mathrm{n}=351,95 \% \mathrm{CI} \pm 3.3 \%)$ respondents who answered about their exposure to overtime work, shift and night work, and lack of time (Fig. 5), $53.7 \%(\mathrm{n}=217,95 \%$

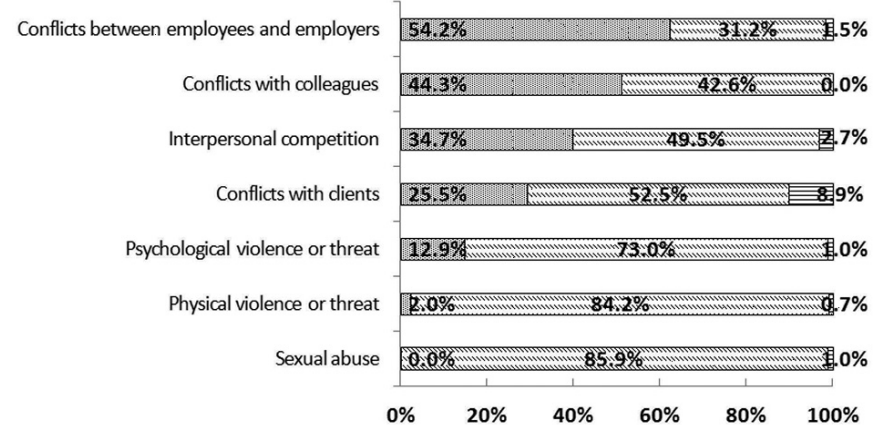

娄Yes, thereare these situations $₫$ No, there are not these situations $\boxminus$ Hard to answer

Fig. 4. Most common psychosocial risk situations in forestry, agriculture, and construction.

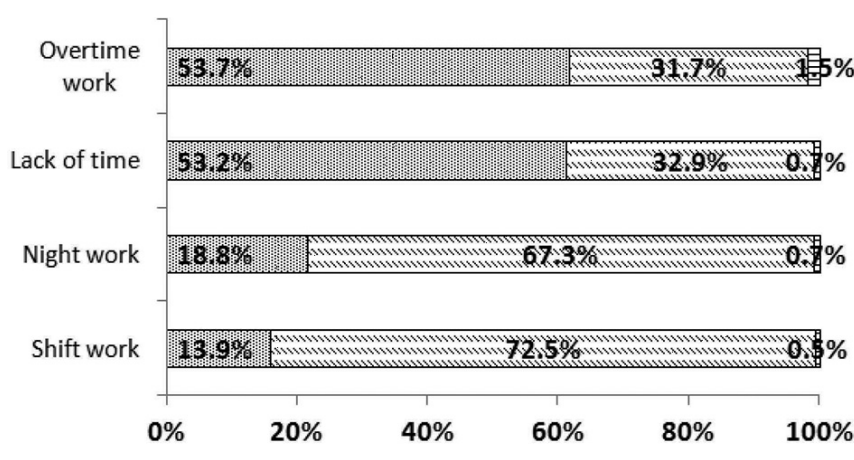

閣Yes, I work this way $\mathrm{WNo}$ I do not work this way 目 Hard to answer

Fig. 5. Lack of time, overtime, night and shift work in construction, agriculture and forestry industries.

$\mathrm{CI} \pm 4.9 \%)$ worked overtime, $53.2 \%(\mathrm{n}=215,95 \% \mathrm{CI} \pm$ $4.9 \%$ ) experienced lack of time in their workplace, $18.8 \%$ $(\mathrm{n}=97,95 \% \mathrm{CI} \pm 4.09)$ had night shifts and $13.9 \%(\mathrm{n}=$ $48,95 \% \mathrm{CI} \pm 3.62$ ) worked in shifts.

Most of the respondents in this group could control their job planning and pace. 91.7\% $(n=370,95 \%$ CI \pm 2.79$)$ responded that they could control their job planning and $94.9 \%(n=381,95 \% \mathrm{CI} \pm 2.15)$ that they could control their job pace (Table 1).

Comparison of prevalence of psychosocial risk factors between industries and their groups. The results show that job satisfaction differed between the industries and their groups (Table 2). Compared to respondents in Group 1 , those working in construction, forestry, and agriculture were less satisfied with their jobs; $87.3 \%$ in Group 1 and $71.8 \%$ in Group 2 responded positively concerning satisfaction with the job. Construction workers were most dissatisfied with their jobs and educational workers were the most satisfied. Job satisfaction statistically differed among industries and their groups.

Interpersonal competition was significantly more common in Group 1, 50.4\% responded to being exposed to this psychosocial risk factor in their workplaces, compared to $41.2 \%$ of respondents in Group 2. Public administration workers, compared with other industry workers, experienced more interpersonal competition $-52.0 \%$ responded affirmatively compared with $34.6 \%$ cases among forestry and agriculture workers.

There was a significant difference in occurrence of conflicts between colleagues between industries, their groups and (Table 2). In Group 1 conflicts with colleagues were more common than in Group 2, public administration workers were exposed the most while agriculture and forestry workers were the least exposed to this psychosocial risk factor. An affirmative answer to this question was given by $59.2 \%$ respondents of Group 1 and 51.0\% of Group 2, 59.9\% of workers in public administration and $42.9 \%$ in agriculture and forestry.

Conflicts with clients were more common among those working in education and public administration (Table 2). 
COMPARISON OF PREVALENCE OF INTERPERSONAL COMPETITION, JOB SATISFACTION, AND CONFLICTS BETWEEN INDUSTRIES AND THEIR GROUPS

\begin{tabular}{|c|c|c|c|c|c|c|c|}
\hline & $\begin{array}{c}\text { Public } \\
\text { administration }\end{array}$ & Education & $\begin{array}{l}\text { Forestry, } \\
\text { agriculture }\end{array}$ & Construction & $\chi^{2}$ & df & $p$ \\
\hline+ & $86.4 \%$ & $88.5 \%$ & $76.5 \%$ & $67.4 \%$ & 34.2 & 3 & $<0.001$ \\
\hline - & $13.6 \%$ & $11.5 \%$ & $23.5 \%$ & $32.6 \%$ & & & \\
\hline+ & \multicolumn{2}{|c|}{$87.3 \%$} & \multicolumn{2}{|c|}{$71.8 \%$} & 29.4 & 1 & $<0.001$ \\
\hline- & \multicolumn{2}{|c|}{$12.4 \%$} & \multicolumn{2}{|c|}{$28.2 \%$} & & & \\
\hline
\end{tabular}

\begin{tabular}{|c|c|c|c|c|c|c|c|}
\hline & $\begin{array}{c}\text { Public } \\
\text { administration }\end{array}$ & Education & $\begin{array}{l}\text { Forestry, } \\
\text { agriculture }\end{array}$ & Construction & $\chi^{2}$ & $\mathrm{df}$ & $p$ \\
\hline+ & $52.0 \%$ & $49.1 \%$ & $34.6 \%$ & $40.9 \%$ & 12.0 & 3 & $<0.01$ \\
\hline- & $48.0 \%$ & $50.9 \%$ & $65.4 \%$ & $52.8 \%$ & & & \\
\hline+ & \multicolumn{2}{|c|}{$50.4 \%$} & \multicolumn{2}{|c|}{$41.2 \%$} & 6.2 & 1 & 0.01 \\
\hline- & \multicolumn{2}{|c|}{$49.6 \%$} & \multicolumn{2}{|c|}{$58.8 \%$} & & & \\
\hline
\end{tabular}

Conflicts with colleagues

\begin{tabular}{|c|c|c|c|c|c|c|c|}
\hline & $\begin{array}{c}\text { Public } \\
\text { administration }\end{array}$ & Education & $\begin{array}{l}\text { Forestry, } \\
\text { agriculture }\end{array}$ & Construction & $\chi^{2}$ & $\mathrm{df}$ & $p$ \\
\hline+ & $59.9 \%$ & $58.7 \%$ & $42.9 \%$ & $58.6 \%$ & 13.8 & 3 & $<0.01$ \\
\hline- & $40.1 \%$ & $41.3 \%$ & $57.1 \%$ & $41.4 \%$ & & & \\
\hline+ & \multicolumn{2}{|c|}{$59.2 \%$} & \multicolumn{2}{|c|}{$51.0 \%$} & 5.1 & 1 & 0.02 \\
\hline- & \multicolumn{2}{|c|}{$40.8 \%$} & \multicolumn{2}{|c|}{$49.0 \%$} & & & \\
\hline
\end{tabular}

Conflicts with clients

\begin{tabular}{|c|c|c|c|c|c|c|c|}
\hline & $\begin{array}{c}\text { Public } \\
\text { administration }\end{array}$ & Education & $\begin{array}{l}\text { Forestry, } \\
\text { agriculture }\end{array}$ & Construction & $\chi^{2}$ & df & $p$ \\
\hline+ & $58.2 \%$ & $55.1 \%$ & $22.9 \%$ & $40.9 \%$ & 50.1 & 3 & $<0.001$ \\
\hline- & $41.8 \%$ & $44.9 \%$ & $77.1 \%$ & $59.1 \%$ & & & \\
\hline+ & \multicolumn{2}{|c|}{$56.5 \%$} & \multicolumn{2}{|c|}{$32.7 \%$} & 39.6 & 1 & $<0.001$ \\
\hline- & \multicolumn{2}{|c|}{$43.5 \%$} & \multicolumn{2}{|c|}{$67.3 \%$} & & & \\
\hline
\end{tabular}

Conflicts between employees and employers

\begin{tabular}{|c|c|c|c|c|c|c|c|}
\hline & $\begin{array}{c}\text { Public } \\
\text { administration }\end{array}$ & Education & $\begin{array}{l}\text { Forestry, } \\
\text { agriculture }\end{array}$ & Construction & $\chi^{2}$ & $\mathrm{df}$ & $p$ \\
\hline+ & $68.4 \%$ & $57.3 \%$ & $57.8 \%$ & $68.7 \%$ & 9.7 & 3 & 0.02 \\
\hline - & $31.6 \%$ & $42.7 \%$ & $42.2 \%$ & $31.3 \%$ & & & \\
\hline+ & \multicolumn{2}{|c|}{$62.2 \%$} & \multicolumn{2}{|c|}{$63.5 \%$} & 0.1 & 1 & 0.7 \\
\hline - & \multicolumn{2}{|c|}{$37.8 \%$} & \multicolumn{2}{|c|}{$36.5 \%$} & & & \\
\hline
\end{tabular}

+ , satisfied; -, dissatisfied

More than one half of Group 1 respondents (56.5\%) reported that they had conflicts with clients and the most exposed group was public administration workers (58.2\%). The least exposed group to this risk factor was agricultural and forestry workers $(22.9 \%$ replied experiencing conflicts with clients). In Group 2, 32.7\% respondents admitted having conflicts with their clients. These differences between industries and their groups were statistically significant.

Conflicts with employers were common in both industry groups; $62.2 \%$ in Group 1 and $63.5 \%$ in Group 2 answered that they had conflicts with their employer. The difference between industries was statistically significant, but not between industry groups.
Psychosocial violence was more common in Group 1 than in Group 2 and the difference was statistically significant (Table 1) $-31.3 \%$ respondents in Group 1 reported that they were exposed to psychological violence, compared to $15.0 \%$ in Group 2. The most exposed were public administration workers and the least exposed were forestry and agricultural workers.

Most of the respondents replied that they were not exposed to physical violence - $97.7 \%$ respondents in Group 2 ( $\mathrm{n}=$ $340)$ and $86.8 \%$ in Group $1(n=349)$ replied negatively. Workers in Group 1 were more exposed to physical violence than respondents in Group 2; $13.2 \%$ educational and public administration workers and $2.3 \%$ forestry, agricul- 
tural and construction workers reported on having situations of physical violence in their workplace. The difference was statistically significant between industries and industry groups. Physical violence as a risk factor was most common in public administration (17.6\% replied affirmatively) and the least exposed were agricultural and forestry workers (3.6\% replied affirmatively).

Exposure to psychosocial risk factors that were linked to the organisation of work in shift and night work significantly differed between industries but not between their groups (Table 3). Shift work was most common in public administration and least common in construction - $23.4 \%$ of public administration workers responded that their job was organised in shifts compared with $11.0 \%$ such respondents in the construction industry. Similarly as for shift work, public administration workers worked in night shifts more than any other industry workers in this study; $36.4 \%$ of public administration workers worked in night shifts compared with $7.6 \%$ respondents in educational workers.

Overtime work was more common among forestry, agricultural and construction workers (Table 3). 62.9\% respondents in Group 2 reported that they worked overtime, compared with $36.9 \%$ in Group 1. The difference between industries and industry groups was statistically significant. Educational workers were least exposed to overtime work; $33.0 \%$ responded affirmatively. Overtime work was most common in forestry and agricultural workers $(63.0 \%$ were

Table 3

COMPARISON OF PREVALENCE OF SHIFT, NIGHT, AND OVERTIME WORK BETWEEN INDUSTRIES AND THEIR GROUPS

\begin{tabular}{|c|c|c|c|c|c|c|c|}
\hline \multicolumn{8}{|c|}{ Shift work } \\
\hline & $\mid \begin{array}{c}\text { Public ad- } \\
\text { ministration }\end{array}$ & Education & \begin{tabular}{|c|} 
Forestry, \\
agriculture
\end{tabular} & $\begin{array}{c}\text { Construc- } \\
\text { tion }\end{array}$ & $\chi^{2}$ & $\mathrm{df}$ & $p$ \\
\hline+ & $23.4 \%$ & $17.0 \%$ & $21.4 \%$ & $11.0 \%$ & 10.9 & 3 & 0.01 \\
\hline- & $76.6 \%$ & $83.0 \%$ & $78.6 \%$ & $89.0 \%$ & & & \\
\hline+ & \multicolumn{2}{|c|}{$19.8 \%$} & \multicolumn{2}{|c|}{$16.0 \%$} & 1.8 & 1 & 0.2 \\
\hline- & \multicolumn{2}{|c|}{$80.2 \%$} & \multicolumn{2}{|c|}{$84.0 \%$} & & & \\
\hline
\end{tabular}

Night work (working more than 2 hours between 22.00-6.00)

\begin{tabular}{|c|c|c|c|c|c|c|c|}
\hline & $\begin{array}{l}\text { Public ad- } \\
\text { ministration }\end{array}$ & Education & $\begin{array}{c}\text { Forestry, } \\
\text { agriculture }\end{array}$ & $\begin{array}{l}\text { Construc- } \\
\text { tion }\end{array}$ & $\chi^{2}$ & $\mathrm{df}$ & $p$ \\
\hline+ & $36.4 \%$ & $7.6 \%$ & $28.1 \%$ & $16.0 \%$ & 57.5 & 3 & $<0.001$ \\
\hline - & $63.6 \%$ & $92.4 \%$ & $71.9 \%$ & $84.0 \%$ & & & \\
\hline+ & \multicolumn{2}{|c|}{$20.2 \%$} & \multicolumn{2}{|c|}{$21.8 \%$} & 0.3 & 1 & 0.6 \\
\hline - & \multicolumn{2}{|c|}{$79.8 \%$} & \multicolumn{2}{|c|}{$78.2 \%$} & & & \\
\hline
\end{tabular}

Overtime work

\begin{tabular}{l|c|c|c|c|c|c|c}
\multicolumn{2}{l}{ Overtime work } \\
\hline $\begin{array}{c}\text { Public ad- } \\
\text { ministration }\end{array}$ & Education & $\begin{array}{c}\text { Forestry, } \\
\text { agriculture }\end{array}$ & $\begin{array}{c}\text { Construc- } \\
\text { tion }\end{array}$ & $\chi^{2}$ & df & $p$ \\
\hline+ & $41.8 \%$ & $33.0 \%$ & $63.0 \%$ & $62.8 \%$ & 53.2 & 3 & $<0.001$ \\
- & $58.2 \%$ & $67.0 \%$ & $37.0 \%$ & $37.2 \%$ & & & \\
+ & $36.9 \%$ & $62.9 \%$ & 50.1 & 1 & $<0.001$ \\
- & $63.1 \%$ & $37.1 \%$ & & &
\end{tabular}

$\overline{+, \text { satisfied; }-, \text { dissatisfied }}$ exposed to this risk factor), compared with the other study industries. Lack of time was a psychosocial risk factor equally common in all industries and industry groups, with no significant differences.

\section{DISCUSSION}

Comparing the prevalence of psychosocial risk factors in different industries and their groups, a gender difference should be taken into account. Most of respondents in Group 1 were women $(74.9 \%, \mathrm{n}=302)$ and most of Group 2 respondents were men $(75.0 \%, \mathrm{n}=303)$. The gender difference between industry groups was statistically significant. Gender influences the prevalence of psychosocial risk factors, and several studies have revealed the importance of this factor. Women tend to experience more cognitive symptoms if they are exposed to conflicts at work, or if the job demands rise which is due to responsibilities women have at home and also limited control at work and lower salaries compared with men (Gunn et al., 2012). Women also reported on having more stress at work than men and overall they responded to being exposed to more occupational risk factors than men (Anonymous, 2013a).

Job satisfaction varied among different industries and the difference was statistically significant. Educational and public administration workers were more satisfied with their job than respondents in Group 2 and the main reasons were the creativity $(52.8 \%, \mathrm{n}=186)$ and certainty of their job $(48.6 \%, \mathrm{n}=171)$ and social insurance $(47.7 \%, \mathrm{n}=168)$. Similar reasons of job satisfaction were identified in a study exploring the prevalence of psychosocial risk factors in public administration. The certainty of the job and knowing that those working in public administration are harder to fire are the most common reasons of job satisfaction in public administration workers (Bytyqi et al., 2010).

The difference between interpersonal competition in both industry groups was statistically significant. This psychosocial risk factor was more common in educational and public administration work $(50.4 \%, \mathrm{n}=200)$ compared with forestry, construction and agricultural work $(41.2 \%, \mathrm{n}=$ 140). The availability of foreign studies about interpersonal competition is limited and therefore it is difficult to compare the results of this study with other results.

Conflicts between employers and employees were common in both industry groups $-62.2 \%(\mathrm{n}=250)$ of respondents in Group 1 and 63.5\% $(n=219)$ in Group 2 reported on conflicts with their employers. No significant differences were found between industries or their groups. The prevalence of this psychosocial risk factor in the studied industries was not compared in other studies, but conflicts with work givers was mentioned as a risk factor in other studies. In a study on violence against teachers, the most common cause of violence was the school dean $(45.6 \%)$ (Tiesman et $a l ., 2013)$. In a study of violence in the workplaces of agricultural and forestry workers, the way of dealing with con- 
flicts is thought to be a major factor influencing job satisfaction and health of employers (Smedley et al., 2007).

In Group 1 conflicts between colleagues and conflicts with clients were more common than in Group 2 and the difference between these 2 groups was statistically significant. The biggest difference occurred in answers to questions about conflicts with clients - those working in education and public administration experienced almost two times more conflicts compared with agricultural, forestry, and construction workers $(56.5 \%, \mathrm{n}=218$ vs. $32.7, \mathrm{n}=103)$. It was observed that greater time of contacts with clients resulted in more conflicts. In a study of prevalence of psychosocial risk factors in educational work, interpersonal relationships with colleagues and the employer, and also conflicts with them, were more common causes of stress than dealing with conflicts or other problems with pupils or their parents (Eres et al., 2011). In a study carried out in Japan, $18.9 \%$ of firemen responded on having conflicts with colleagues of their own shift (Violenti et al., 2013).

Violence, both physical and psychological was more common in Group 1 respondents $-13.2 \%(\mathrm{n}=52)$ were exposed to physical and $31.3 \%(n=126)$ to psychological violence, compared with $2.3 \%(n=8)$ respondents in Group 1 having to deal with physical and $15.0 \%(n=52)$ with psychological violence. Violence in educational and public administration work is a major risk factor recognised also in other studies. Studies have shown that pupils and their parents are usually the ones who cause violence (Bauer et al., 2007; Fox and Stallworth, 2010; Tiesman et al., 2013). No significant difference was found between industries and their groups in this question and none of the respondents in industry Group 2 responded affirmatively to this question, making it difficult to compare the results with other studies. Respondents in Group 1, who worked in public administration, were more exposed to physical violence $(83.9 \%, \mathrm{n}=$ $26)$, compared with educational work $(42.2 \%, \mathrm{n}=19)$, indicating that physical violence was more common in industries where employees work with clients.

Occurrence of overtime work significantly differed between industries and their groups. This psychosocial risk factor was more common in Group 2, where 62.9\% $(\mathrm{n}=217)$ responded to have worked overtime, compared with $36.9 \%$ (n $=148$ ) in Group 1. Some similarities can be found in other studies. In a study carried out in Germany it was found that educational workers tended to work more than thought at first. The work time of a regular teacher working full time and in addition with other responsibilities exceeds the amount of a normal work week and reaches at least 51 hours per week. This overtime work is due to extra tasks teachers have, like preparing for classes, checking tests and other work positions (Bauer et al., 2007). The fact that most forestry, construction and agricultural workers work overtime is consistent with findings in other studies, for example, in a study about work-family conflicts it was found that $76.3 \%$ respondents working in construction work overtime (Tarek et al., 2009).
Lack of time as a psychosocial risk factor did not vary between industries and industry groups $-62.7 \%(\mathrm{n}=252)$ respondents in Group 1 and $61.8 \%(\mathrm{n}=215)$ in Group 2 reported on lacking time in their workplace. This psychosocial risk factor was the most common among the industries, indicating that lack of time is an overall risk factor for workers of different industries in Latvia.

\section{REFERENCES}

Anonymous (1986). International Labour Organisation. Psychosocial factors at work: recognition and control. Available at: http://www.who.int/occupational_health/publications/ILO_WHO_1984_report_of_the_joint_committee.pdf (accessed 9 September 2016).

Anonymous (2008). Latvijas Republikas bērnu un ǵimenes lietu ministrija. Valsts bērnu tiesību aizsardzības inspekcija. Aptaujas "Savstarpējās attiecības starp skolēniem, skolotājiem un vecākiem" rezultāti. [Results of inquiry "Interpersonal relationships between pupils, parents and teachers"] Retrieved June 1, 2013, from www.bti.gov.lv/in_site/tools/download.php?file=files/text/ieciet\%C4\%ABba.doc.ppt (in Latvian).

Anonymous (2010). International Agency for Research on Cancer. Agents Classified by the IARC Monographs, Volumes 1-116. Retrieved September 12, 2016, from http://monographs.iarc.fr/ENG/Classification/List_of_Classifications.pdf

Anonymous (2013a). European Agency for Safety and Health at Work. European opinion poll on occupational safety and health. Available at: https://osha.europa.eu/en/safety-health-in-figures/eu-poll-press-kit-2013. pdf (accessed 5 May 2013).

Anonymous (2013b). Latvijas Republikas Labklājības ministrija. Darba aizsardzības jomas attīstības pamatnostādnes 2008. - 2013. gadam. [Strategy for the Development of the Labour Protection Field 2008-2013]. Retrieved May 4, 2013, from

http://www.1m.gov.1v/upload/darba_tirgus/darba_aizsardziba/ kor_20080417_tiesibu20akti_lmpamn.pdf (in Latvian).

Anonymous (2014). European Commision. Communication from the Commission to the European Parliament, the Council, the European Economic and Social Committee and the Committee of the Regions on an EU Strategic Framework on Health and Safety at Work 2014 - 2020. Retrieved September 12, 2016, from

http://eur-lex.europa.eu/legal-content/EN/TXT/PDF/?uri=CELEX: 52014DC0332

Anonymous (2016a). European Agency for Safety and Health at Work. European Survey of Enterprises on New and Emerging Risks - Managing Safety and Health at Work. Retrieved September 9, 2016, from https://osha.europa.eu/sites/default/files/publications/documents/en/publications/reports/esener1_osh_management/en_ESENER_report.pdf

Anonymous (2016b). European Agency for Safety and Health at Work. Second European Survey of Enterprises on New and Emerging Risks (ESENER-2) - Overview Report: Managing Safety and Health at Work. Retrieved September 9, 2016, from

https://osha.europa.eu/sites/default/files/publications/documents/ ESENER\%20II\%20-\%20Overview.pdf

Bauer, J., Unterbrink, T., Hack, A., Pfeifer, R., Buhl-Griesshaber, V., Müller, U., Wesche, H., Frommhold, M., Seibt, R., Scheuch, K., Wirsching, M. (2007). Working conditions, adverse events and mental health problems in a sample of 949 German teachers. Int. Arch. Occup. Environ. Health, 80 (5), 442-449.

Bytyqi, F., Reshani, V., Hasani, V. (2010). Work stress, job satisfaction and organizational commitment among public employees before privatization. Eur. J. Soc. Sci., 18 (1), 156-162. Available at:

http://ejournal.narotama.ac.id/files/Work\%20Stress,\%20Job\%20Satisfact ion\%20and\%20Organizational\%20Commitment.pdf (accessed 26 May 2013).

Campbell, F. (2006). Occupational stress in the construction industry. Survey 2006. Available at: 
http://www.ciob.org.uk/sites/ciob.org.uk/files/WEB-INF/files/documents/stress.pdf (accessed 2 June 2013).

Eglīte, M. Darba medicīna [Occupational Medicine]. Rīgas Stradiṇa universitāte, Rīga. 834 lpp. (in Latvian).

Eres, F., Atanasoska, T. Occupational stress of teachers: A comparative study between Turkey and Macedonia. Available at:

http://www.erisee.org/downloads/2013/2/Occupational\%20Stress$\% 20$ of\%20Teachers-\%20A\%20Comparative\%20Study $\% 20$ Between $\% 20$ Turkey\%20and\%20Macedonia\%202011\%20ENG.pdf (accessed 4 May 2013).

Fox, S., Stallworth, L. E. (2010). The battered apple: An application of stressor-emotion-control/support theory of teachers' experience of violence and bullying. Human Relations, 63, 927-954.

Gunn, K. M., Kettler, L. J., Skaczkowski, G. L., Turnbull, D. A. (2012). Farmers' stress and coping in a time of drought. Rural Remote Health, 12, 2071. Available at:
http://www.rrh.org.au/articles/subviewnew.asp?ArticleID=2071 (accessed 4 June 2013).

Goetsch, D. L. (2015). Occupational Safety and Health for Technologists, Engineers, and Managers. ( $8^{\text {th }}$ edn.). Pearson Education, New Jersey. 702 pp.

Smedley, J., Dick, F., Sadhra, S. (2007). Oxford Handbook of Occupational Health. Oxford University Press, New York. 932 pp.

Sobeih, T., Salem, O., Genaidy, A., Abdelhamid, T., Shell, R. (2009). Psychosocial factors and musculoskeletal disorders in the construction industry. J. Constr. Eng. Manag., 135 (4), 267-277.

Tiesman, H., Konda, S., Hendriks, S., Mercer, D., Amandus, H. (2013). Workplace violence among Pennsylvania education workers: Differences among occupations. J. Safety Res., 44, 65-71.

Violenti, J. M., Fekedulegn, D., Andrew, M. E., Charles, L. E., Hartley, T. A., Vila, B., Burchfiel, C. M. (2011). Shift work and long-term injury among police officers. Scand. J. Work Environ. Health, 37 (3), 173-185.

Received 16 September 2016

\section{PSIHOSOCIĀLO DARBA VIDES RISKA FAKTORU IZPLATĪBA DAŽĀDĀS NOZARĒS LATVIJĀ}

Pētījuma hipotēze, ka psihosociālie darba vides riska faktori ir vairāk izplatīti nozarēs, kas saistītas ar garīgu darbu, piemēram, izglītības un valsts pārvaldē (1. grupa), salīdzinot ar nozarēm, kurās prevalē fizisks darbs kā būvniecība, lauksaimniecība un mežsaimniecība (2. grupa), tika apstiprināta. Izplatītākie psihosociālie darba vides riska faktori 1. grupā ir konflikti darbinieku vidū, starp vadītājiem un darbiniekiem, kā arī laika trūkums un nepieciešamība komunicēt ar klientiem. Vardarbība, jo sevišķi fiziskā un psiholoğiskā, ir izplatīts riska faktors 1. grupā, visbiežāk vardarbības veicējs ir klients. Nozaru 2. grupā izplatītākie riska faktori ir virsstundu darbs, konflikti starp vadītājiem un darbiniekiem, laika trūkums un nepieciešamība komunicēt ar klientiem. Virsstundu darbs ir izplatītākais no psihosociālajiem riska faktoriem būvniecības, lauksaimniecības un mežsaimniecības nozarēs. 